\title{
GEOTECHNICAL FEATURES OF HISTORICAL ARCHITECTURAL MONUMENTS OF CENTRAL ASIA
}

\author{
A.Zh. Zhussupbekov ${ }^{I}$, A. Issina ${ }^{2}$, Y. Iwasaki ${ }^{3}$ Sh. Kenjaev', I. Usmankhodjaev ${ }^{5}$ \\ ${ }^{1}$ L.N.Gumilyov Eurasian National University, Nur-Sultan, KAZAKHSTAN \\ ${ }^{2}$ Saken Seifullin Kazakh Agricultural Technical University, Nur-Sultan, KAZAKHSTAN \\ ${ }^{3}$ Geo-Research Institute, Osaka, JAPAN \\ ${ }^{4}$ Tashkent Institute of Architecture and Civil Engineering, Tashkent, UZBEKISTAN \\ ${ }^{5}$ Tashkent Institute of Architecture and Civil Engineering, Lolazor St. 70, Samarkand, UZBEKISTAN
}

\begin{abstract}
In this paper geoenvironmental problems of the historical cities of Central Asia are considered, climatic, geotechnical, hydrogeological characteristics of the studied objects, their constructive decision and the analysis of deformations of elevated and underground construction designs are provided. Main reasons for deformations of monuments of architecture of Central Asia: uneven rainfall of soil of the basis in the most overloaded sites of designs of the building; seismic influences; violation of temperature moisture conditions and moisture; anthropogenous influence (especially notable in the historical cities of Samarkand and Bukhara where monuments of architecture are influenced by vibrations from traffic). In the paper the offered observation method of monuments of architecture of Central Asia and results of observation of the mausoleum Arystan-Bab and a mosque and minaret Kalon for 2014 is described.
\end{abstract}

Key words: geotechnical analysis, anthropogenic impacts, constructions of architectural monuments

\section{ГЕОТЕХНИЧЕСКИЕ ОСОБЕННОСТИ ИСТОРИЧЕСКИХ АРХИТЕКТУРНЫХ ПАМЯТНИКОВ ЦЕНТРАЛЬНОЙ АЗИИ}

\author{
А.Ж. Жусупбеков ${ }^{1}$, А.З.Исина ${ }^{2}$, И.Ивасаки ${ }^{3}$, Ш.Кенжеев ${ }^{4}$, И. Усманходжсаев $^{5}$ \\ ${ }^{1}$ Евразийский национальный университет им. Л.Н. Гумилева, г. Нур-Султан, Республика КАЗАХСТАН \\ ${ }^{2}$ Казахский агротехнический университет им. С.Сейфуллина, г. Нур-Султан, Республика КАЗАХСТАН \\ ${ }^{3}$ И. Ивасаки, директор, Институт гео-исследований, Осака, ЯПОНИЯ \\ ${ }^{4}$ Ташкентский архитектурно-строительный институт, г. Ташкент, УЗБЕКИСТАН \\ ${ }^{5}$ Ташкентский архитектурно-строительный институт, г. Самарканд, УЗБЕКИСТАН
}

\begin{abstract}
Аннотация: В статье рассматриваются геоэкологические проблемы исторических городов Центральной Азии, приводятся климатические, геотехнические, гидрогеологические характеристики исследуемых объектов, их конструктивные решения и анализ деформирования надземных и подземных строительных конструкций. Основные причины деформирования памятников архитектуры Центральной Азии: неравномерное выпадание грунта из основания в наиболее перегруженных участках конструкций здания; сейсмические воздействия; нарушение температурно-влажностного режима и влажности; антропогенные воздействия (особенно заметны в исторических городах Самарканд и Бухара, где на памятники архитектуры влияют вибрации от движения транспорта). В статье описан предложенный метод наблюдения за памятниками архитектуры Центральной Азии и результаты наблюдения за мавзолеем Арыстан-Баб, а также мечетью и минаретом Калон за 2014 год.
\end{abstract}

Ключевые слова: геотехнический анализ, антропогенные воздействия, конструкции памятников архитектуры 


\section{INTRODUCTION}

The history of our ancient land leaves deep into the millennia. Holding an advantageous geographical position, the connecting North with the South, the East with the West, Central Asia was the important center on the road of a caravan which became history under the name of the Great Silk Way. On branches of this ancient transcontinental highway not only trade developed - there was an active process of mutual enrichment of ideas, cultures, traditions, religions, crafts and technologies.

Considering all importance of the huge cultural heritage, which got to us carrying out numerous researches and monitoring of technical condition of significant monuments of architecture of the Central Asian region for the purpose of its preservation is necessary for descendants.

One of the types of the works directly concerning cultural heritage, demanding greater financial influences, but which aren't receiving the due amount of financing is carrying out engineering-geological and geotechnological researches of historical monuments of architecture of Central Asia.

At the present stage the majority of monuments of architecture of the countries of Central Asia faced a problem of destruction of the bases under the influence of climatic factors. One of the most common causes of deformations are uneven rainfall which, in turn, cause deformations and destructions of the bearing designs - the bases, walls, columns, overlappings, the arches, crossing points window and doorways.

The integrated approach to restoration practically was only designated due to wide use of engineering restoration, and concerning necessary taking note of changes of the geological environment on safety of historical territories is made so far very little.

\section{GEOENVIRONMENTAL PROBLEMS IN THE HISTORICAL CITIES OF CENTRAL ASIA}

Environmental problems are connected with changes of historically developed geological and hydrogeological mode. In particular is a raising of ground waters and increase in their structure of concentration of salts, increase in moisture content and salt in the soil. These phenomena started promoting actively deformation of designs and an intensive erosion of walls and bases of monuments of architecture. Especially strongly historical buildings of the cities located in low territories of Central Asia (Bukhara, Khiva) suffer. Now the listed above negative facts negatively influence and the architecture monuments which are in rather favorable foothill territories of Central Asia: in such as Samarkand, Shakhrisabz, Shymkent, etc. however here increase in humidity in soil and raising of ground waters is generally connected with a human factor: urbanization and development of communication systems. For this reason studying of this problem needs to be conducted in two directions: in the global - change of a geoecological situation of Central Asia, in local scale - to look for evidencebased ways of decrease in level of its influence for the purpose of preservation of masterpieces of world famous monuments of architecture. We will begin with the main thing: a geoecological situation in the region (Guseva 2000).

For the last decade there were serious problems connected with preservation of world famous masterpieces of architecture. In particular, the salted ground waters owing to the aggression in relation to construction materials as a result of difficult physical and chemical processes start erodirovat intensively underground and elevated designs of monuments therefore often there are deformations, and in certain cases and their final fracture. As an example, it is possible to bring catastrophic destruction of one of minarets of the Chor-Minor complex, strong deformations of a complex Tim Abdulkhan, a complex Ark and an inclination of minarets in Bukhara or deformations of some monuments in Samarkand, the 
Ichang-Kala complex in Khiva (Abdurashidov et al. 2011).

\section{GEOTECHNICAL, HYDRO-GEOLOGICAL AND CONSTRUCTIVE CHARACTERISTICS OF MONUMENTS OF ARCHITECTURE OF CENTRAL ASIA}

The mausoleum of Hodge Ahmed Yassavi (XIV$X V$ cen.) (Figure 1).

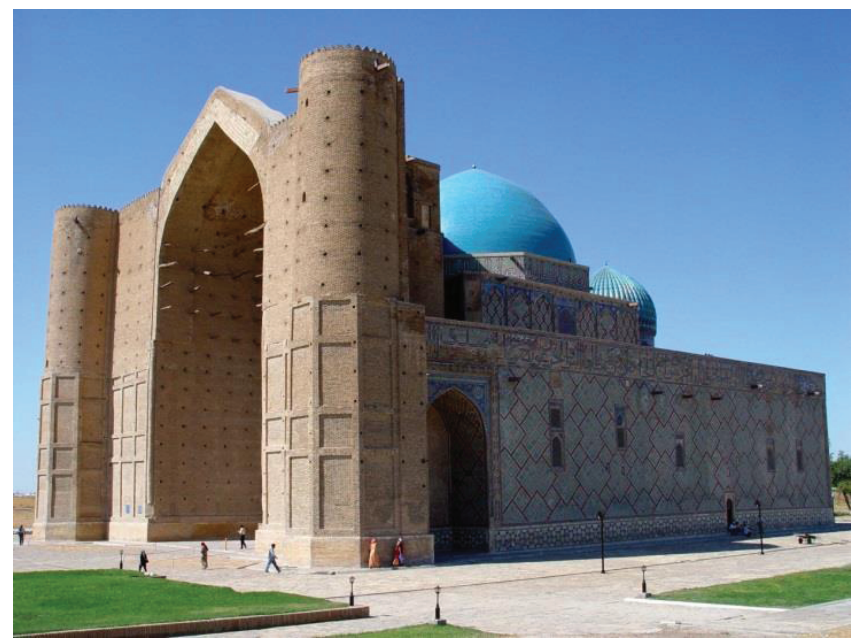

Figure 1. The Mausoleum of Hodge Ahmed Yassavi.

Soils. The prolyuvialny loams with a general power of 5-7 $\mathrm{m}$ quarternary allyuvialno containing form the basis of a monument interlay also lenses of sandy loams. They are spread water containing gravel with the power from 4 to 24

$\mathrm{m}$. Sandy loams are developed mainly in the top part of a section. Sandy loams of light brown color, macroporous, loessial, uniform. Loam of brown color, dense with inclusion of carbonate particles. Sand dusty, meets in the form of lenses, mainly on contact with a galechnik, color its gray and brown, uniform. Pebble soil is presented by sedimentary breeds, fragments well rounded, so-so thickened and extended, as filler sand serves.

Ground waters. Ground waters for June, 2011 are opened with developments at a depth of 7,6-7,8 $m$ from an earth surface. In relation to situation level of ground water (LGW) for September, 1997, LGW in June, 2011 is recorded 1,4- 1,5 m below.

Foundations. The main part of a construction is built on clay gulfs, in South side under portal part the rubble foundations up to $7 \mathrm{~m}$ in depth are executed.

In 1993 the technology of jet cementation of soil was applied to strengthening of the basis of a monument by the Turkish company. Strengthening and the device of piles was carried out to two stages. At the first stage of work were carried out for walls to $2 \mathrm{~m}$. At the second stage strengthening of the basis of walls up to $4 \mathrm{~m}$ thick was made. Total length of a pile is about $15 \mathrm{~m}$. Thus, the support of all construction through piles on thickness of solid soil is reached.

Deformations. Due to the lack of emergence of essential deformations on a monument to the first cycle it wasn't given due consideration though at this moment there was a deep soaking of soil and the basis of the foundations of monuments of the complex. The second cycle of rise in level of ground waters caused already external deformations of the building of a monument, in December, 1982 there was a destruction of the top restoration number of stalactites of a dome of the Main Hall - Kazanlyk.

The mausoleum of Arystan-Bab (XIV-XV cen.) (Figure 2).

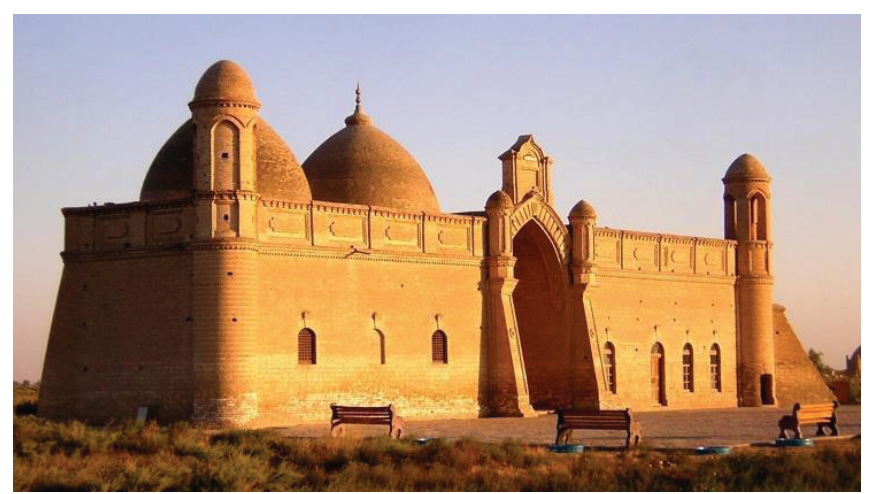

Figure 2. The Mausoleum of Arystan-Bab. 
Soils. The analysis of average values physic mechanical property of soil on holes and an additional driving of holes allow directly under a sole without foundations walls and the bases with depth to $1,0 \mathrm{~m}$ to allocate 3 engineering- geological element (EGE):

1. EGE - loam of a firm-semi-firm consistence, not collapsible, uniform, with rare inclusions of fragments of a brick and the vegetable remains in the top part of a layer, 1,0 - 1,5 m $(0,9-1,0 \mathrm{~m}-$ on wells $)$, it is possible to assume that it is the loam layer, or the layer executed by method of "gulf" in a trench width exceeding thickness of walls which is artificially condensed in an open trench; it possesses quite certain and rather close indicators of physic mechanical properties 2 EGE;

2. EGE - loam dark brown a firm-semi-firm consistence, not collapsible, with roots of vegetation, 3,3-3,6 m (on wells);

3. EGE - sandy loam brown, a plastic and fluid consistence with pro-layers of sand dusty (to 0,2 m) with an opened power of 3,5-3,7 m (Report, 2004).

Ground waters. LGW near a contour of the monument is opened at depths of 1,9-2,7 m (August, 1984), 2,75-2,85 m (May, 2004) and 3,14-3,37 m (August, 2004).

Foundations. The foundations are arranged under the most loaded parts of a construction. Under minarets the foundations are executed from a stone-plitnyak on clay solution. Materials of the bases are in a good shape.

On a hole № 10 up to $1,5 \mathrm{~m}$ in depth, in a place of a joint of a longitudinal wall on axis $A$ and the left minaret, lack of the foundation under a wall which laying leans on three rows of preparation from a detrital brick is revealed. Their basis is the uniform layer of loam of the first EGE. The hole № 11 from the outer side of a wall on axis 4 up to $0,7 \mathrm{~m}$ in depth, opened the concrete plate $17-20$ thick see above it the layer of dry, fragile roofing material, and over it one more concrete layer about $9 \mathrm{~cm}$ thick, revetted outside with a thin facing tile is found. Over this layer there is a wall bricklaying.

Deformations. In a laying of walls cracks on all facades are noted. During observation it is established that width of disclosure of cracks makes from 0,1 to $2 \mathrm{~mm}$. In a place of interface of a minaret to a wall (a northeast facade) the crack reaches $2 \mathrm{~cm}$ and goes mainly on laying seams. All cracks in a laying come to an end, without reaching a socle. Cracks, generally in places of reduction of thickness of walls settle down. Indoors tombs № 1 are noted the deformations in a laying menacing to safety of a construction. These are cracks and smashing of a brick in a laying of basic part of arches, split of a brick in places of support of angular arches in northeast and northwest walls. In a northeast wall of a crack in a laying of basic part of arches have extent to $2 \mathrm{~m}$.

The Registan ensemble (XV-XVII cen.) (Figure 3).

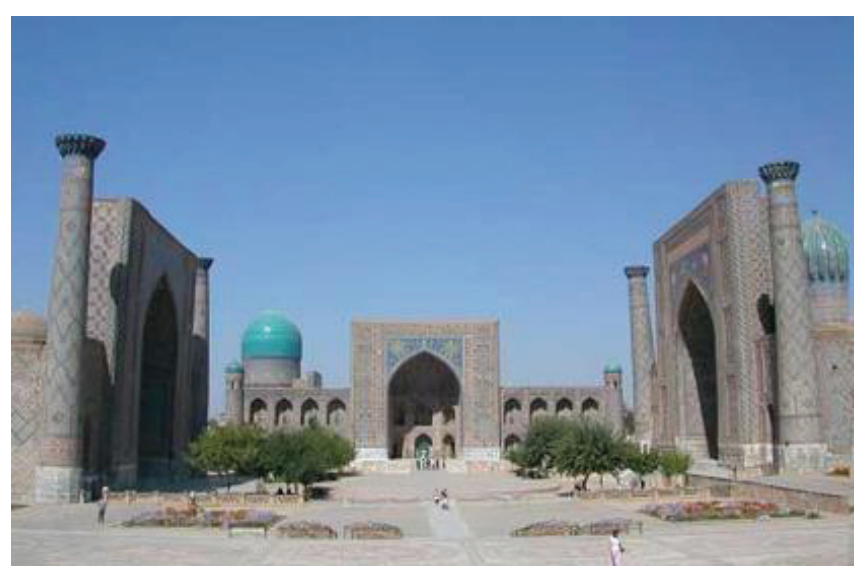

Figure 3. The Registan Ensemble.

Soils. On a site the different depth of weak anthropogenous soil is noted: the greatest depth of 12,6 $\mathrm{m}$ takes place directly under the dome foundations at the western wall and is almost twice less $(6,8$ $\mathrm{m})$ on wall length on the southern site.

Foundations. The foundations under buildings have various constructive decision, depth and are made of different materials. Under walls the tape foudations, and under racks and poles the separate step 
are, as a rule, executed. For the device of the foundations blocks and rubble stones of Chupan-atinsky slate or marble limestone on ganchevy and limy solution with use in some cases of ashes, and also the foundations of the caravanserai which was earlier existing on this place were used (the burned brick on limy and ganchevy solution). By observations it is established that the lower part of a laying is made of quarrystone on clay solution, all other part of a laying is executed on ganchevy solution. In a design of the foundations the wooden reinforcing elements are found.

Deformations. Judging by the tilted racks of northern and southern galleries and other architectural forms, deformation of a mosque proceeds rather long time. Tool supervision over the building is begun since 1983. It is established that uneven rainfall of soil of the basis in the most overloaded building design sites were the main reason of deformation of the building. In particular more uneven deformations underwent designs of the western wall and foundations under a dome that led to emergence of a huge number of through cracks in walls, coverings, arches and floors. The Bibi-Hanym mosque (XIV-XV cen.) (Figure 4).

Soils. The quarternary alluvial prolyuvialny loams with a general power of 5-7 m containing form the basis of a monument interlay also lenses the lessovidnykh of sandy loams. They are spread water containing gravel with the power from 4 to $24 \mathrm{~m}$. Sandy loams are developed mainly in the top part of a section. Sandy loams of light brown color, macroporous, loessial, uniform. Loam of brown color, dense with inclusion of carbonate particles. Sand dusty, meets in the form of lenses, mainly on contact with a galechnik, color its gray and brown, uniform. Pebble soil is presented by sedimentary breeds, fragments well rounded, so-so thickened and extended, as filler sand serves.

Foundations. The foundations of small mosques are put from plates of a fragmentary Chupanatinsky stone by the size on the person $(60-80)$ $\times 25 \mathrm{~cm}$, on the same solution, as a laying.

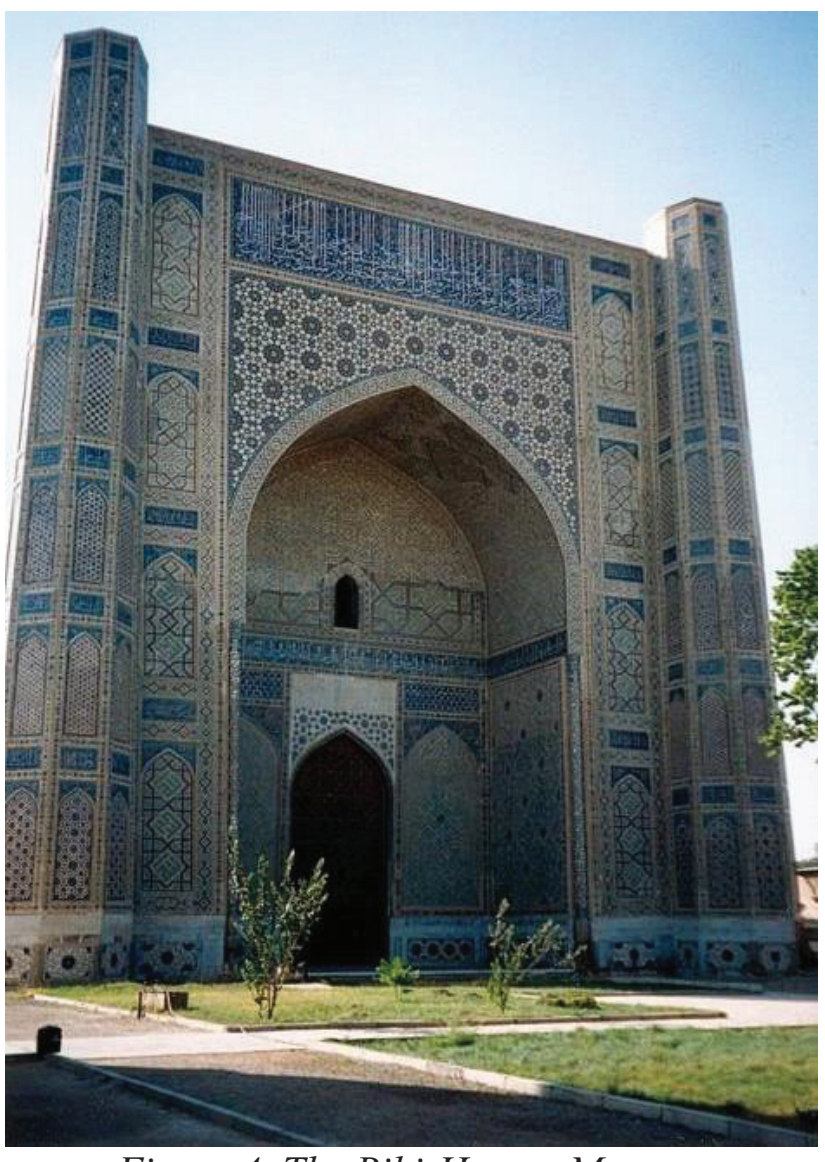

Figure 4. The Bibi-Hanym Mosque.

In the foundations of the Big mosque, various on a laying and upon transition to elevated parts kyr. Depth of the foundations various, in some places it doesn't exceed 0,5-0,6 $\mathrm{m}$ from a day surface of the earth.

Deformations. In a body of old layings and a minaret traces of inclined cracks are visible. It means that before destruction the minaret was strongly rejected from a portal. Existence of cracks in the central dome part of the Big mosque is noted.

The Ishratkhona (XV cen.) (Figure 5).

Soils. The prolyuvialny loams with a general power of 5-8 m quarternary allyuvialno containing form the basis of a monument interlay also lenses the lessovidnykh of sandy loams. They are spread water containing gravel with the power from 4 to $24 \mathrm{~m}$. Sandy loams are developed mainly in the top part of a section. Sandy loams of light brown color, 
macroporous, loessial, uniform. Loam of brown color, dense with inclusion of carbonate particles. Sand dusty, meets in the form of lenses, mainly on contact with a galechnik, color its gray and brown, uniform.

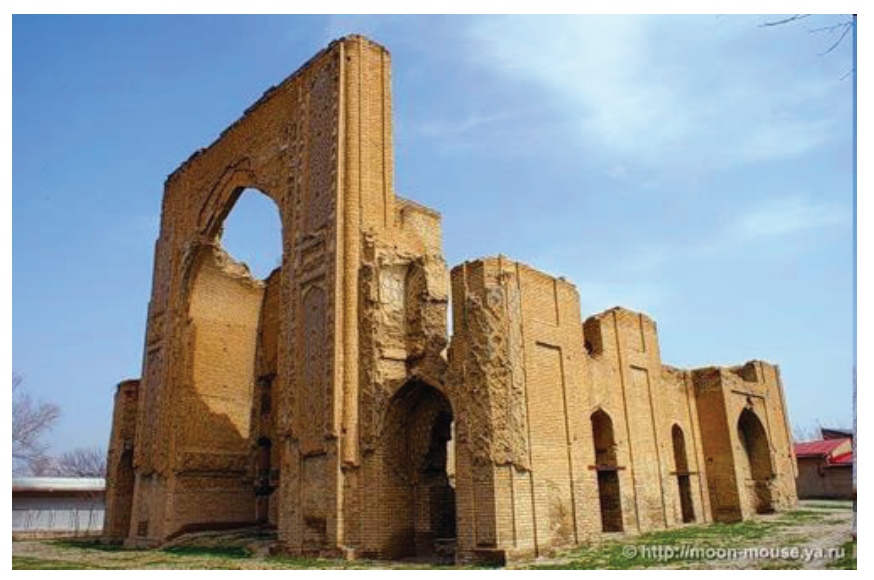

Figure 5. The Ishratkhona.

Ground waters. Because the minimum level of ground waters during the summer period reaches $3,50-3,80 \mathrm{~m}$, there is a capillary rising of water in solution to its moistening.

Foundations. The foundations of the building have various depth (from 1,3 to 4,2 $\mathrm{m}$ ) and is presented by a rubble laying from a fragmentary Chupan-atinsky stone on clay solution. Under a portal the rubble laying has power down of nearly $4 \mathrm{~m}$, being lowered on depth about 5,5 $\mathrm{m}$ from earth level. Existence in soil of marlaceous layers assumes the assumption that the basis before construction was previously killed and condensed.

Deformations. The building of a monument is strongly destroyed and many elements are bared. The design of an underground crypt is executed from the flat arch leaning on massive side support. Support of the arch aren't connected with the bases of the main building that gives it the chance independently to be deformed irrespective of building rainfall. In 1903 the dome and a drum of the central room failed, and in 1904 the remains of a drum and the top parts supporting its arches finally collapsed. The main reason for long destruction of vaulted and arch designs is connected with gradual decrease in durability of material in the most loaded basic parts and destruction of integrity of designs.

In the course of complex research of historical monuments of architecture of Central Asia the main reasons for an unsatisfactory condition of some constructive elements of a monument are established:

- uneven rainfall of soil of the basis in the most overloaded sites of designs of the building;

- seismic influences;

- violation of temperature moisture conditions and moisture. In our case moisture is formed for the account:

- absolute and relative humidity of the air environment generally during the winter period;

- condensation moisture;

- penetrations of soil moisture into thickness of the protecting designs into the spring period;

- atmospheric moisture during the autumn and spring periods;

- technical moisture which arises in the course of performance of construction works.

- anthropogenous influence (especially notable in the historical cities of Samarkand and Bukhara where monuments of architecture are influenced by vibrations from traffic).

\section{OBSERVATION METHOD FOR HISTORICAL MONUMENTS OF ARCHITECTURE OF CENTRAL ASIA}

The offered observation method of historical monuments of architecture of Central Asia will unite in itself a package of measures on research, preservation and forecasting of behavior of construction designs of historical monuments of architecture:

1. Collecting and an assessment of retrospective engineering-geological information in the territory of a monument and in the territory adjoining 
a monument;

2. Carrying out hydrogeological researches for the purpose of specification of a depth of ground waters and its dynamics, definition of a chemical composition;

3 . Heatphysical calculation of a monument of architecture;

4. Collecting and the analysis of the deformations given about character and speed of their development; control of shrinkage of a monument or its elements;

5. Identification of the most rational methods of prevention of further development of deformations in the bearing designs;

6. Use of numerical information technologies for drawing up the correct forecast of work of constructive elements of monuments of architecture for the next 10, 20 and 100 years;

7. Preservation of authenticity of object unless development of deformations brings to full of destruction of object of cultural heritage.

Heatphysical calculations are made for definition of optimum temperature moisture conditions of rooms and are aimed at decrease in accumulation of condensation humidity on a surface of walls.

Degree of stability of flying designs or construction in general, durability and deformability of materials on static and dynamic (seismic) influences is made by means of special engineering settlement programs. By results of these calculations the weakest places in designs come to light and issues of their strengthening are resolved.

Systematization of the most often destroyed sites allows to conduct long supervision over a condition of constructive and finishing elements, to reveal and eliminate the main reasons for damage and destruction.

The results of observation of the mausoleum Arystan- Bab in April, 2014

Foundations. Materials of the foundations of a construction are in a good shape, any violations or deformations is noted.

Socle. Separate bricks in a socle are removed.
Also laying seams in the lower part of a socle are removed. On a surface of a bricklaying of a socle of northwest, southwest and northeast facades salt spots are noted.

Walls. In general bricks of walls are in a satisfactory condition. Aeration of separate bricks on facades, and also seams on buttresses, in the lower and top parts of walls (parapet), in a laying of a northern minaret is noted (Figure 6).

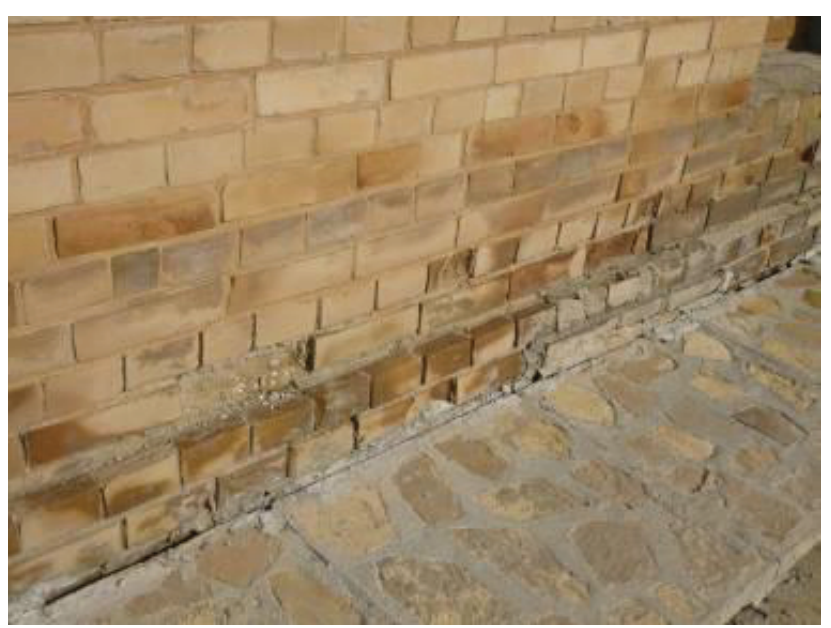

Figure 6. Destruction of Separate Bricks in a Laying of a Socle and Walls of the Mausoleum Arystan-Bab.

On a surface of a bricklaying of walls of northwest, southwest and northeast facades salt spots (Figure 7) are noted. Walls are moistened in these parts on 1,5-2 m.

On a laying of buttresses of northwest and southeast facades lichens are noted.

Overlappings. In a tomb № 1 seams in a dome laying are removed inside. Outside seams in a laying of domes are also removed in separate places. In an arch laying separate bricks are removed, on a surface of a laying salt spots are from the inside noted. On a parapet in 1996 the plastering of horizontal surfaces was executed by angidridovy solution. During inspection the plastering exfoliated from a surface and was divided into pieces. Possibly, there is no adhesion of solution and a surface of a laying of a parapet. 


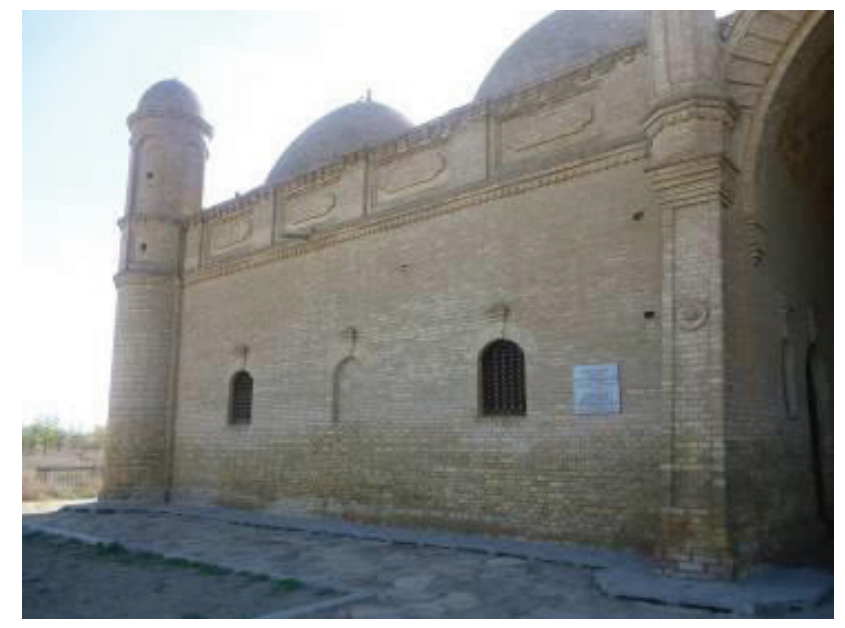

Figure 7. Moistening of the Lower Part of a Northeast Facade of the Mausoleum Arystan-Bab.

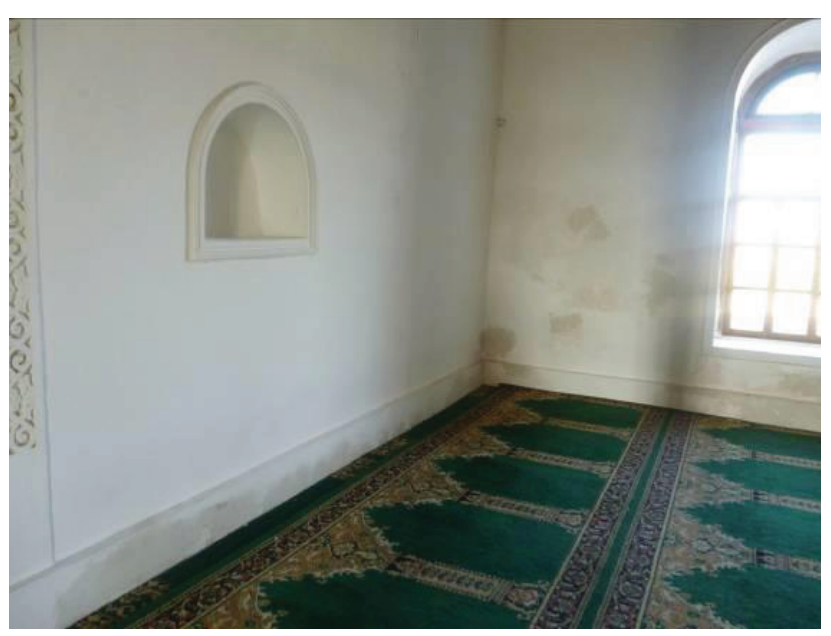

Figure 8. The Interior of Mausoleum Arystan-Bab.

The laying of domes and turrets is covered with lichens. In an interior of a mosque moistening of a blanket of plaster is noted. Floors are carpeted, thus carpets in a half-baked state that testifies to moistening of plates of a floor of a mosque (Figure 8).

Blind area. Round the mausoleum the blind area is executed from a stone-plitnyak on cement mortar. As cement mortar interferes with moisture evaporation, the blind area round a construction was sorted on width of $40-50 \mathrm{~cm}$.

\section{Analysis of results of a chemical composition of ground waters}

Comparison of results of the chemical analysis of ground waters of 1984 (on wells 268 and 269 from depths of 2,37 and 2,46 m), 2004 (holes 2 and 3 from depths of 2,8 and $2,7 \mathrm{~m}$ ) and 2014 (from depth of 2,8 m) is executed (Table 1).

Table 1. The Average Values of Indicators of the Chemical Analysis of Ground Waters

\begin{tabular}{|c|c|c|c|c|c|}
\hline \multirow{2}{*}{ Indicator } & \multirow{2}{*}{$\begin{array}{l}\text { Dimen- } \\
\text { sion }\end{array}$} & \multicolumn{3}{|c|}{ Value } & \multirow{2}{*}{ Note } \\
\hline & & \begin{tabular}{|l|}
1984 \\
\end{tabular} & 2004 & 2014 & \\
\hline $\begin{array}{l}\text { Bicarbonate } \\
\text { alkalinity } \\
(\mathrm{HCO} 3)\end{array}$ & $\mathrm{mg} / \mathrm{l}$ & 244 & 814 & 769 & \\
\hline \begin{tabular}{|c|} 
Hydrogen \\
indicator of $\mathrm{PH}$
\end{tabular} & & $\begin{array}{l}7,6- \\
7,8\end{array}$ & $\begin{array}{c}7,65- \\
7,7\end{array}$ & 7,2 & \\
\hline $\begin{array}{l}\text { Content of mag- } \\
\text { nesian Mg salts }\end{array}$ & $\mathrm{mg} / \mathrm{l}$ & 468 & 1232 & 973 & \\
\hline $\begin{array}{c}\text { Content of caus- } \\
\text { tic alkalis } \\
(\mathrm{Na}+\mathrm{K})\end{array}$ & $\mathrm{mg} / \mathrm{l}$ & 2520 & 1244 & 728 & decrease \\
\hline \begin{tabular}{|c|} 
The content of \\
sulfates in terms \\
of SO4 ions \\
\end{tabular} & $\mathrm{mg} / \mathrm{l}$ & 5520 & 2952 & 819 & decrease \\
\hline \begin{tabular}{|c|} 
General rigidity \\
$(\mathrm{Ca}+\mathrm{Mg})$
\end{tabular} & mgecu/l & 107 & 129 & 118 & \\
\hline \begin{tabular}{|c|} 
Dry rest \\
(mineralization)
\end{tabular} & $\mathrm{g} / 1$ & 13,5 & 10,2 & 7,9 & \\
\hline
\end{tabular}

The changes of salt structure at very high mineralization it is seen, are connected with the general falling of LGW, especially after works on cleaning and deepening of the water lowering channels on external borders of the territory of a necropolis. It and reduction of compounds of caustic alkalis and content of sulfates, and also falling of the general mineralization of ground water. The effect of water decrease would be higher at restoration of part of the filled-up canal (up to 250$300 \mathrm{~m}$ long) from entrance on the territory of a necropolis (the southeast party). From this party waters from irrigation aryk of the above-located farmland most intensively arrive (Issina and Zhussupbekov 2015). 
The results of observation of the complex PoiKalyan in July, 2014

This huge vertical pillar dominating over the city put from a zhzhenny brick gives a complete idea of forms of Central Asian minarets - the round, expanded to a bottom tower, below diameter of $10,5 \mathrm{~m}$ and $5,7 \mathrm{~m}$ above. The general height of a minaret of $47,5 \mathrm{~m}$, but its multimeter basis is hidden in the depth of the earth, under century stratifications, however on the basis of K.S. Kryukov researches. The depth of the foundations makes about 12,0 $\mathrm{m}$, and also the socle part of a minaret which was in an occupation layer of the earth that gave the chance to restore the area level corresponding to time of construction of the Karakhanidsky mosque and a minaret was naked. Over a trunk of a minaret the sixteen-arch rotunda of a lamp leaning on the acting ranks of a laying issued in the form of stalactite eaves is arranged. On top of a minaret the cool brick ladder leaning on a trunk and external walls of a minaret conducts. Rise on a platform of a lamp is carried out on a spiral staircase in a minaret trunk. The external surface is decorated by terracotta plates and figured bricks the sizes of $260 \times 260 \times 50 \mathrm{~mm}$. on ganch solution with addition of a kyr. The front surface of a minaret is covered with the magnificent relief pattern from a brick broken into ten ornamental belts, any of them doesn't repeat another. The roof is laid out from a zhzhenny brick on ganch solution.

The minaret Kalon is connected by the bridge transition to a roof of a cathedral mosque Kalon from where it is possible to get in a minaret and to rise on the narrow and cool brick spiral staircase numbering 105 steps.

The ladder, $990 \mathrm{~mm}$ wide, is arranged round a minaret kernel - an axial trunk of Ø2250 mm (Figure 9). Each step gets married a vaulted arch height on average of $2450 \mathrm{~mm}$ the relations of the parties in respect of on average $211 / 340 \mathrm{~mm}$ and equal to a proportion 0,62 (golden ratio) which corresponds, reached us in antique literature divi- sion of a piece in the extreme and average rela-

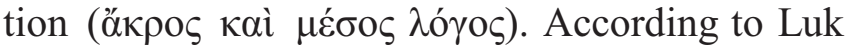
Pachuoli of the contemporary Leonardo da Vinci, called this relation "a divine proportion". The term "golden ratio" (goldener Schnitt) was entered into use by Martin Om in 1835.

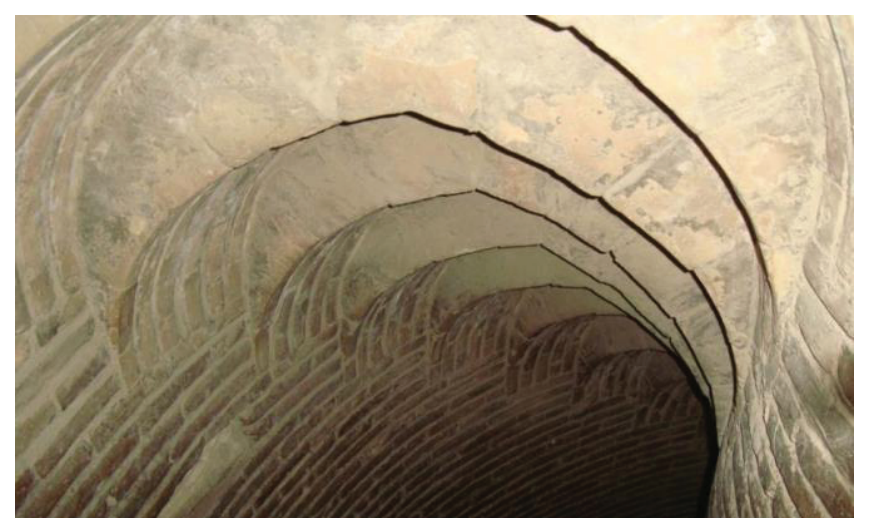

Figure 9. The Arch of the Spiral Staircase of the Minaret Kalon.

Under the mosque arches Kalon (Maszhidi colon) gathered to 12 thousand people, the building occupies the space 1ga. At uniform type of the building are absolutely various works of architecture. Its construction was complete in 1514.

The mosque on the architecture belongs to type four ayvan, with the big yard and the arch and dome gallery surrounding it. Serves as a support of multidome overlapping of the gallery bypassing the yard of the mosque Kalon monumental poles.

The rectangular yard is framed with the galleries consisting of 288 domes, the basis it 208 columns form. The longitudinal axis of the yard comes to the end with the maksury - the portal and dome volume of the building with the crosswise hall over which the blue massive dome on a mosaic drum rises.

The main entrance - East is decorated with the big portal issued by a mosaic, and on each side it two blue domes tower. On the central part the internal portal of a mosque has an octahedral construction, playing a role of chair. Color facing of facades is created by means of the mosaic and bricks covered with glaze (Report 2014). 


\section{Engineering-geological structure of a site}

In the geomorphological relation the platform of researches is dated for the second over an inundated terrace of the river Zarafshan in the Central part of the Bukhara oasis and put by alluvial deposits of quarternary age.

Directly on a site in a lithologic section two engineering- geological elements (EGE) are allocated: EGE-1 and EGE-2.

First engineering-geological element EGE-1:

- from a surface it is covered with a powerful layer cultural and city adjournment of sandy and loamy structure with a large number inclusion of fragments of bricks, fights of pottery.

The layer is opened in intervals of depths of $0,0-14,5 \mathrm{~m}$. The opened power changes from 6,8 to $14,5 \mathrm{~m}$.

The second engineering-geological element EGE2 consists of:

- the loams of gray and dusty color from damp to water- saturated with a sandy loam pro-layer, it is opened in intervals of depths of $6,8-15,0 \mathrm{~m}$ the opened power changes from 0,5 to $4,7 \mathrm{~m}$.

Ground waters belong to nonaggressive in relation to concrete on sulfate-resistant brands of cement. Category of soil - the second. Standard depth of seasonal frost penetration in soil $-0,8 \mathrm{~m}$. Seismicity of the region of 8 points (Conclusion, 1980).

\section{The results of observation}

At the observation time of constructions the natural sizes, sections of designs, determination of physic mechanical properties of materials of construction designs, dynamic characteristics of designs, and also over sensitive seism metric devices were defined by devices of nondestructive control and technical diagnostics.

In the course of inspection defects, damages and the deformations which appeared in use were revealed:

- The minaret - destructions of part of a lamp, formation of through cracks 5-10 mm wide in arch locks, over lighting apertures disclosure of 3-5 mm wide were the main types of damages from dynamic (seismic), which are located from the level of the earth 12,$60 ; 17,60 ; 22,80 ; 27,60 ; 31,80 \mathrm{~m}$ and in other places of the top part of a construction. - The laying of a brick corresponds to the II category of equal $0,84-1,25 \mathrm{~kg} / \mathrm{cm}^{2}$, M-75 brick brand.

- overlapping - a lamp floor bricklaying after repair work is in a satisfactory condition. Disruptions of communication with a bricklaying of walls it isn't observed.

- The trabeation of a lamp is in a satisfactory condition.

- the ladder - a brick ladder leans on a trunk and external walls of a minaret. A satisfactory technical condition, steps didn't lose the bearing ability. Deformations and destructions it isn't observed.

- the roof is laid out from a zhzhenny square brick on ganch solution. In places insignificant cracks are observed. Destructions in a roof resulted from influence of an atmospheric precipitation and seismic influences.

- mosque walls brick thickness in the central part of $1200 \mathrm{~mm}$, in lateral walls $-700 \mathrm{~mm}$, back part $-800 \mathrm{~mm}$, the laying of a brick corresponds to the II category of equal 0,70

$-0,95 \mathrm{~kg} / \mathrm{cm}^{2}, \mathrm{M}-75$ brick brand.

On perimeter of walls are observed, from outer side the aeration of solution and the humidified sites in internal walls extending from floor level to 1,8-2,0 $\mathrm{m}$ on height (Figure 10)

- In walls on perimeter of a mosque and in a main entrance at the level of the second floor vertical and inclined cracks, disclosure of 2,0-8,0 mm wide, owing to seismic influences are observed.

- floors of a mosque are arranged from brick tiles with the sizes $260 \times 270 \times 40 \mathrm{~mm}$. Because of soaking in left-side gallery of a mosque round columns occurred soil shrinkage, and at distance of 1,0-2,0 $\mathrm{m}$ from columns the exit of soil of $3,0-5,0 \mathrm{~cm}$ is observed. The exit of soil resulted, apparently, from a frost penetration in soil. 


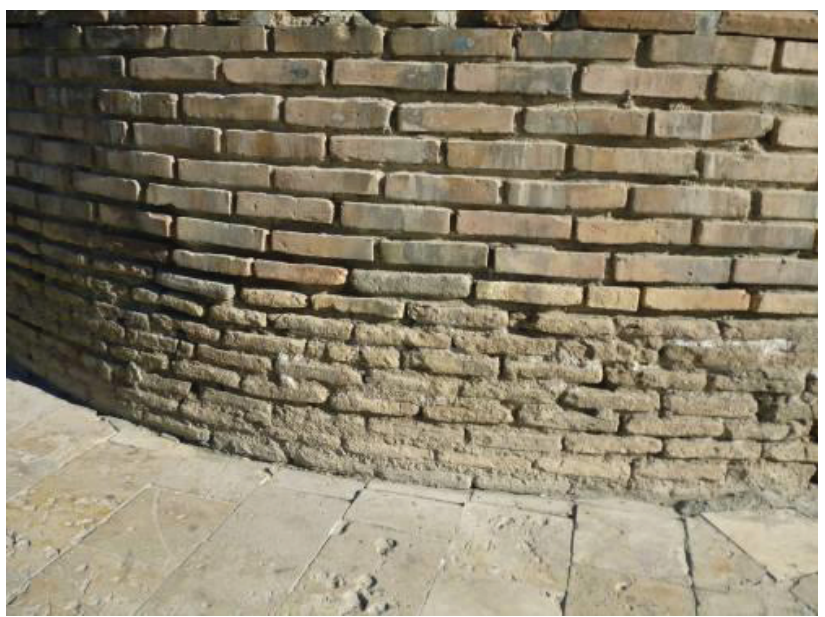

Figure 10. Aeration of Solution in Bricklaying Seams of Mosque Kalon.

Further, on the basis of the conducted on-site investigations and theoretical researches, it is planned to carry out:

- additional engineering-geological researches of sites and research by a SIR-3000 system georadar;

- calculation for an assessment of the intense deformed condition of designs at static loadings;

- calculation on seismic influences and an assessment of seismic stability of designs;

- development of constructive actions and recommendations about strengthening of designs.

\section{SUMMARY AND CONCLUSIONS}

Climatic, geotechnical and hydrogeological features of historical monuments of architecture of Central Asia are considered and was made the analysis of deformations of monuments of architecture of Central Asia;

The comparative analysis of modern ways of strengthening of the bases and foundations, the deformed monuments of architecture was made and was developed the recommendations about geomonitoring, preservation and protection of historical monuments of architecture;
The results of geotechnical researches were used and formed the basis of the offered observation method of monuments of Central Asia.The observation method of monuments of cultural heritage which purpose is monitoring of an actual state and the forecast of behavior of historical monuments of architecture of Central Asia was developed.

The superficial soil layer to $6 \mathrm{~m}$ is unstable and can't form the basis for a construction because of effect of a capillary raising of underground ground waters.

Application of numerical information technologies will allow to analyze more deeply the architectural and construction achievements corresponding to this or that historical period of time and to conduct monitoring of the happening processes.

Data on results of purposeful engineering-geological researches are among necessary materials; these surveys of design features of a monument, types of the foundatios and about distribution of loads of soil of the bases; data on nature of deformations and speed of their development; materials of supervision over an shrinkage of a monument or its elements.

Preventive conservation of historical monuments of architecture is pledge of their safe operation taking into account temporary and natural and technogenic factors and influence of environment.

\section{REFERENCES}

1. Abdurashidov K.S., Kabulov F.R., Rakhmonov B. K. Inzhenernye problemy arhitekturnyh pamjatnikov [Engineering problems of architectural monuments]. Uzbekistan, Tashkent, FAN, 2011 (in Russian).

2. Guseva L.Yu. Problema ispol'zovanija vodnyh resursov v Central'noj Azii [Problem of use of water resources in Central Asia]. Scientific paper. Almaty: KISI, 2000, pp. 8-15 (in Russian). 
3. Issina A.Z., Zhussupbekov A.Zh. Analysis of geotechnical properties of soils and ground water of Mausoleum Arystan-Bab in South Kazakhstan. // Proceedings of 6th International symposium on Disaster Mitigation in Special Geoenvironmental Conditions, Chennai, India, 2015, pp. 277-280.

4. The conclusion "About engineering-geological conditions of a platform". Uzbekistan, Bukhara, 1980.

5. Report on the complex scientific researches "Engineering - geological and Hydrological Researches for the Mausoleum Arystan-Bab in the South Kazakhstan Area". Kazakhstan, AlmaAta, 2004.

6. The scientific and technical report "An assessment of operational reliability of the mausoleum Samanidov, a minaret and a mosque Kalon in Bukhara". Uzbekistan, Tashkent, 2014.

\section{СПИСОК ЛИТЕРАТУРЫ}

1. Абдурашидов К.С., Кабулов Ф.Р., Рахманов Б.К. Инженерные проблемы архитектурных памятников. - Ташкент: Фан, 2011.

2. Гусева Л.Ю. Проблема использования водных ресурсов в Центральной Азии. Научная статья. Алматы: КИСИ, 2000, с. 815.

3. Issina A.Z., Zhussupbekov A.Zh. Analysis of geotechnical properties of soils and ground water of Mausoleum Arystan-Bab in South Kazakhstan. // Proceedings of 6th International symposium on Disaster Mitigation in Special Geoenvironmental Conditions, Chennai, India, 2015, pp. 277280.

4. The conclusion "About engineeringgeological conditions of a platform". Uzbekistan, Bukhara, 1980.

5. Report on the complex scientific researches "Engineering - geological and Hydrological
Researches for the Mausoleum Arystan-Bab in the South Kazakhstan Area". Kazakhstan, Alma-Ata, 2004.

6. The scientific and technical report "An assessment of operational reliability of the mausoleum Samanidov, a minaret and a mosque Kalon in Bukhara". Uzbekistan, Tashkent, 2014.

A.Zh. Zhussupbekov, Professor, Dr.Sc.; Department of Civil Engineering, L.N. Gumilyov Eurasian National University, 010008, Satpayev street, 2, Nur-Sultan, Kazakhstan;

phone: +7 (7172) 344796;

E-mail: astana-geostroi@mail.ru

A.Issina, $\mathrm{PhD}$, Associate Professor, Department of Architecture and Design, Saken Seifullin Kazakh Agricultural Technical University, 010011, Zhenis ave., 62, Nur Sultan, Kazakhstan; phone: +7 (7172) 31-75-47;

E-mail: isinaasem83@gmail.com

Y. Iwasaki, Director, Geo-Research Institute, Osaka, Japan, 4-3 2, Itachi-bori, Nishi-ku, Osaka 550-0012;

Phone: +81-6-6539-2976;

E-mail:dec19yoshi1+torino@gmail.com

Sh. Kenjaev, Department of Civil Engineering, Tashkent Institute of Architecture and Civil Engineering, Navoi street, 13, Tashkent, Uzbekistan; phone: +7 (7172) 31-75-47;

E-mail: isinaasem83@gmail.com.

I. Usmankhodjaev, Department of Civil Engineering, Tashkent Institute of Architecture and Civil Engineering, Lolazor St. 70, Samarkand, Uzbekistan, 140147;

phone: (+998) 93 330-55-66;

e-mail:uzssmge@gmail.com

Жусупбеков А.Ж., профессор, доктор технических наук; Евразийский национальный университет им. Л.Н. Гумилева; 010008, Республика Казахстан, г. Нур-Султан, ул. Сатпаева, д. 2; тел: +7 (7172)344796;

E-mail: astana-geostroi@mail.ru.

Исина A.3., PhD, ассоциированный профессор, Казахский агротехнический университет им. С.Сейфуллина, 010011, пр. Победы, 62, г. Нур-Султан, Казахстан,

Тел: +7 (7172) 31-75-47;

E-mail: isinaasem83@gmail.com. 
И. Ивасаки, директор, Институт гео- исследований, Осака, Япония, 4-3 2, Itachi-bori, Nishi-ku, Osaka 5500012; phone+81-6-653 2976;

E-mail: dec19yoshi1+torino@gmail.com.

Кенжаев Ш., Строительный факультет, Ташкентский архитектурно-строительный институт, ул. Навои, 13, Ташкент, Узбекистан; тел: +7 (7172) 31-75-47;

e-mail: isinaasem83@gmail.com

Усманходжаев И., Строительный факультет, Ташкентский архитектурно-строительный институт, ул. Лолазор, 70, 140147, Самарканд, Узбекистан, тел: (+998) 93 330-55-66;

E-mail: uzssmge@gmail.com. 